\title{
リンパ管内皮細胞の機能制御における 転写因子・シグナルネットワークの役割
}

\author{
吉松 康裕 ${ }^{1,2}$, 渡部 徹郎 ${ }^{2}$
}

\begin{abstract}
要 旨：Prox1はリンパ管内皮細胞の分化や細胞機能に必須なマスター転写因子である。われわれはこれまで にProx1の機能を制御する転写因子としてEtsファミリー転写因子を, Prox1が制御するシグナル伝達経路とし て血小板由来増殖因子（PDGF）シグナルを同定した。また, Prox1そのものの発現を調節するシグナル因子と して，内皮間葉移行の誘導因子である TGF- $\beta$ を同定した。（J Jpn Coll Angiol 2020; 60: 193-196）
\end{abstract}

Key words: Prox1, lymphatic endothelial cell, platelet-derived growth factor, Ets family transcription factor, transforming growth factor- $\beta$

受付：2020年7月 6 日 受理：2020年 9 月 8 日 公開：2020年 11 月 10 日

\section{ホメオボックス転写因子 Prox1の リンパ管内皮細胞における役割と機能}

ホメオボックス転写因子Prox1は成体において中枢神 経系, 膵臓, 肝臓, レンズ, 筋肉, 精巣など, さまざま な組織や臓器の発生においてそれぞれ重要な役割を果た している。しかし, 脈管系に限れば, リンパ管内皮細胞 に発現が限局している。Prox1はOliverらによってリン パ管発生に必須であることが示されており，現在では Prox1はリンパ管内皮細胞マーカーの一つとして知られ

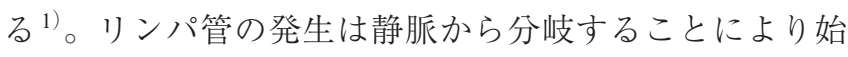
まる。静脈内皮細胞においてリンパ管内皮細胞への分化 能を獲得したLYVE-1（リンパ管内皮細胞マーカーの一 つ）陽性の細胞がProx1 を発現するようになると，血管 内皮細胞増殖因子ファミリーの一つである VEGF-Cへの 走化性を獲得して初期リンパ囊を形成し, これを起点と して全身に向けて伸長していくと考えられている。

しかしながら, Prox1がどのような分子機構を介して リンパ管内皮細胞分化を誘導するかについてはまだ十分 詳細に解析されていなかった。そこで，われわれはマウ 又胚性幹細胞（ES 細胞）から分化させた血管内皮細胞 にProx1を発現させることで, リンパ管の発生期にどの

\footnotetext{
1 新潟大学大学院医歯学総合研究科薬理学分野

2 東京医科歯科大学大学院医歯学総合研究科硬組織病態生化 学分野

doi: $10.7133 /$ jca.20-00032
}

ようなシグナルが機能しているのか，またその役割につ いて解析を行った。通常, 血管内皮細胞は血管内皮増 殖因子VEGF-A の受容体であり，血管内皮細胞マーカー でもある血管内皮増殖因子受容体VEGFR2 を発現してい る。われわれはES細胞由来血管内皮細胞にProx 1 を発現 させることで, 同じ血管内皮増殖因子受容体ファミリー の一つで, VEGF-Cをリガンドとする受容体 VEGFR3の 発現が誘導されることを見出した ${ }^{2)}$ 。これに対して，す でにProx1を発現している皮膚由来のリンパ管内皮細胞 においてはProx1の発現を SiRNAにより低下させると， VEGFR3の発現が低下し, 細胞のVEGF-Cに対する走化 性が低下した。以上から, Prox1はリンパ管内皮細胞が VEGF-Cに対する走化性を発揮するのに必須であること が示された (Fig. 1右 $)^{2)}$ 。

ES 細胞由来血管内皮細胞にProx1を発現させると, 細 胞の運動性が顕著に立進していることが見出されたの でこれを制御するシグナル分子としてintegrinに着目 したところ, integrin $\alpha 9$ の発現が立進していた。同様に ヒト臍帯静脈内皮細胞HUVECにProx1を発現させても, 細胞の運動性が立進し integrin $\alpha 9$ の発現が高くなったこ とから, これに対する中和抗体を作用させたところ, 顕 著に細胞の運動性が低下した。以上から, Prox1がintegrin $\alpha 9$ の発現を介して細胞の運動性を立進させているこ とが示された $(\text { Fig. 1右 })^{2)}$ 。

\section{(c) BY-NC-ND}




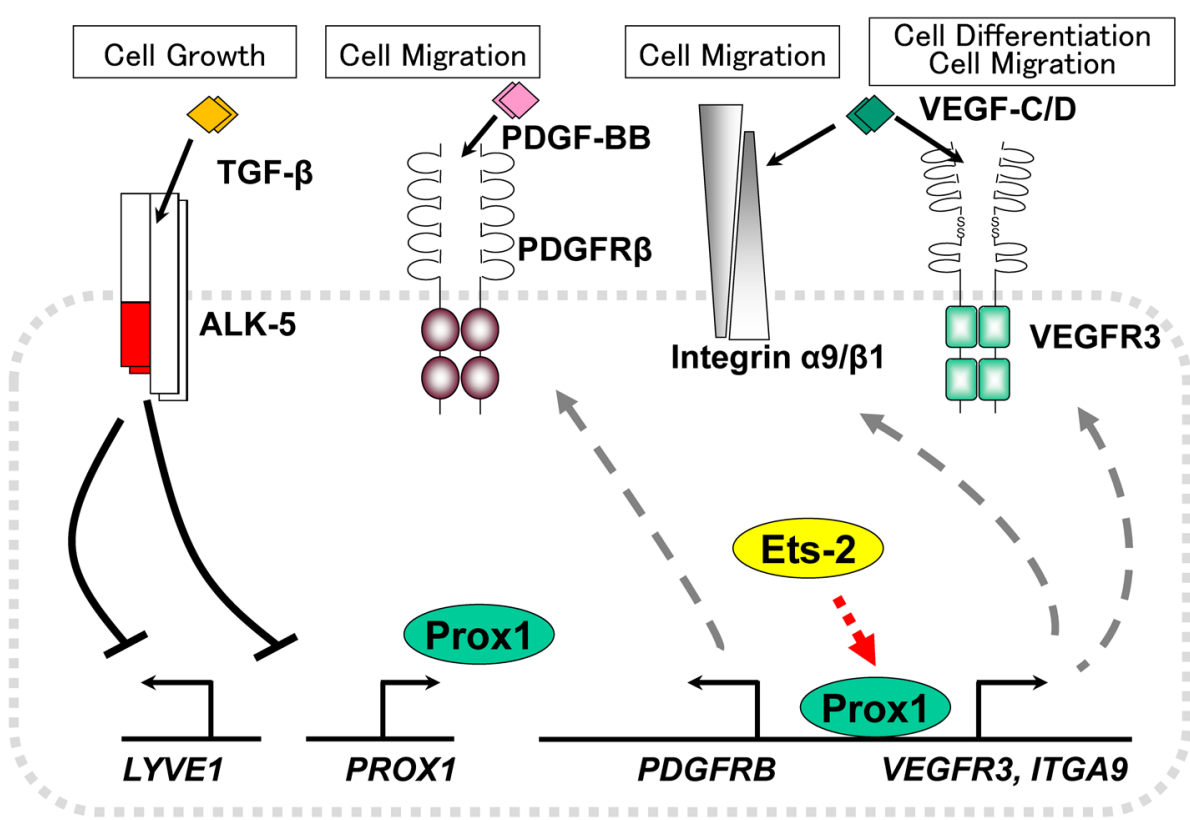

Figure 1 Prox1-related signaling pathways in lymphatic endothelial cells

Prox 1 induces cell differentiation and migration via induction of expression of VEGFR3 and integrin $\alpha 9$ in lymphatic development during embryogenesis. Ets- 2 transcription factor modulates Prox 1 function in the regulation of Prox 1 target genes. PDGFR $\beta$, whose expression is regulated by Prox1, mediates inflammatory and tumor lymphangiogenesis. TGF- $\beta$ downregulates expression of lymphatic endothelial cell (LEC) markers, LYVE1 and Prox1, via its receptor complex including ALK-5. SB431542 is a selective inhibitor of ALK-5.

\section{$\operatorname{Prox1}$ の機能調節因子としての}

\section{Ets ファミリー転写因子の役割と機能}

次にわれわれはProx1がさまざまな組織で発現する ため, リンパ管内皮細胞特異的な機能を発揮するには, Prox1に対して作用する転写共役因子が存在するのでは ないかという仮説を立て, Prox1の機能調節を行う候補 因子としてProx1結合因子を探索した。得られた複数の 因子の中には, Ets-2 というEts ファミリー転写因子が含 まれていた ${ }^{3)}$ 。このEtsファミリー転写因子は血管内皮 細胞でも発現しており，血管新生に扔いて重要な役割を 果たすことが報告されていたが、リンパ管内皮細胞にお ける役割は未解明であった。Prox1が調節する標的遺伝 子の中から Ets-2によって発現調節を受けるものとして, VEGFR3が同定された（Fig. 1右）。HUVECを用いた解 析では, Prox1単独, Ets-2 単独でそれぞれVEGFR3の発 現が充進するが，共発現させると，さらに顕著に発現が 克進した。この作用機構はProx1の標的遺伝子と考えら れる Angpt-2や先述の integrin $\alpha 9$ の発現調節においても 観察された（Fig. 1右）。これらの発現制御が生体でも起 きているかを検証するため, 無菌性の腹膜炎を誘導する 実験モデルに扔いてEts-2をコードするアデノウィルス をマウスに投与したところ，コントロールのアデノウィ ルスに比べて顕著に炎症性のリンパ管新生を充進した。
以上から，Ets-2がリンパ管形成（新生）を正に制御す る転写因子であることが示された ${ }^{3)}$ 。

\section{Prox1 が制御する血小板由来増殖因子（PDGF） シグナルの役割と機能}

CaoらはPDGFを過剩発現させた腫瘍においてはリン パ管新生が充進し，さらにリンパ節転移が充進すること を報告している4)。しかし，炎症やがんに拈いて内因性 のPDGF シグナルが存在するか，さらにこれを阻害する ことでリンパ管新生が抑制されるかについては未解明 であったため, 内因性のPDGF シグナルを阻害すること で，炎症やがんに扔けるリンパ管新生に対するPDGFシ グナルの役割について検討した。PDGFの細胞外ドメイ ンに抗体の Fc 領域を融合させたキメラタンパク質を設 計し，炎症性のリンパ管新生抢よび腫瘍リンパ管新生を 誘導したマウスにおいて，これを用いてPDGFシグナル を抑制したところ, 炎症性掞よび腫瘍リンパ管新生が ともに抑制された ${ }^{5)}$ 。以上の結果から炎症打よびがんに おいてはともにPDGFシグナルが存在しておりリンパ管 新生に寄与していることに加え, 今回設計したPDGF シ グナルの特異的阻害分子がリンパ管新生の抑制に有効で あることが示された。さらに，われわれはこのシグナル の受容体についてProx1により発現調節を受ける可能性 について検討したところ，2種の受容体のうち，PDGFR 


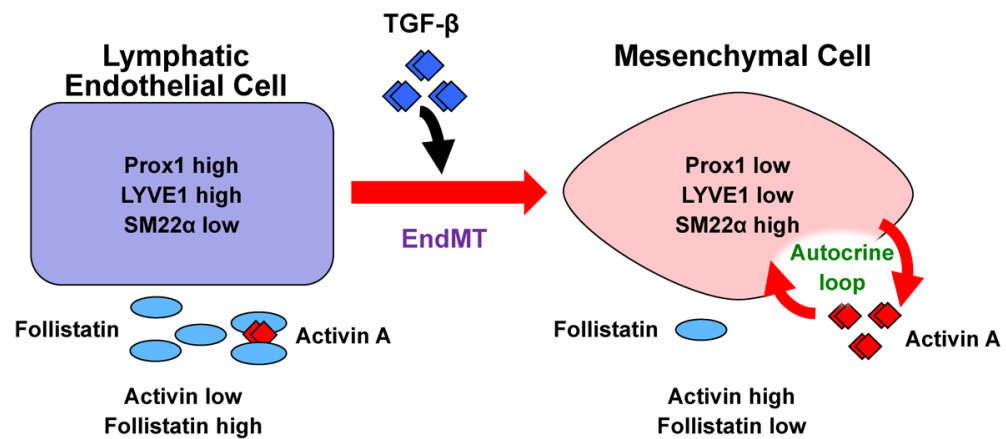

Figure 2 Mechanism of TGF- $\beta$-triggered EndMT in lymphatic endothelial cells

In normal tissues, lymphatic endothelial cells maintain expression of activin A at a high level as well as that of LEC markers such as LYVE1 and Prox1, but suppress that of follistatin, an inhibitory molecule of activin A. In TGF- $\beta$-enriched tissues affected during senescence, inflammation and cancer, TGF- $\beta$ induces EndMT, which is characterized by decreased expression of LEC markers and increased expression of mesenchymal markers including SM22 $\alpha$. During EndMT of LECs, production of Activin A is increased while expression of follistatin is decreased, which leads to activation of autocrine loop of Activin signals. Such changes result in the long-lasting activation of Activin signal in LEC-derived mesenchymal cells and stabilization of EndMT.

$\alpha$ ではなくPDGFR $\beta$ がProx1によって発現調節を受けて いることを見出した (Fig. 1 中央 $)^{5)}$ 。

\section{リンパ管内皮細胞における内皮間葉移行因子 TGF- $\beta$ の役割とその作用機序}

Oka らはTGF- $\beta$ がリンパ管内皮細胞に直接作用して増 殖を抑制し、リンパ管形成に抑制的に働くことを報告し ている ${ }^{6)}$ 。TGF- $\beta$ は上皮間葉移行に挹いて強力な誘導因 子として知られるが, 近年, 内皮細胞にも作用して内皮 間葉移行（Endothelial Mesenchymal Transition: EndMT）を 誘導することが示されている。リンパ浮腫を誘導した病 態モデルや老化した組織では，機能低下を起こしたり ンパ管内皮細胞が観察され, 間葉系細胞マーカーの共 発現が見られることから ${ }^{7-9)}$ ，われわれは，TGF- $\beta$ がリ ンパ管内皮細胞に対しても EndMTを引き起こすと予想 し，ヒトリンパ管内皮細胞を用いて，この役割とその作 用機序について検討した。TGF- $\beta$ の添加により 72 時間後 では, リンパ管内皮細胞マーカーLYVE-1 抒よびProx1 の発現が顕著に低下し，TGF- $\beta$ の受容体阻害剂 SB431542 の添加により顕著に上昇した（Fig. 1左）。一方，間葉系 細胞マーカーであるSM $22 \alpha$ の発現はTGF- $\beta$ の添加により 顕著に上昇し，SB431542の添加により抑制された。さ らに, 間葉系細胞の特徵である細胞の運動性の充進につ いて検討したところ, TGF- $\beta$ の添加により運動性の立進 が観察された ${ }^{10)}$ 。以上から，リンパ管内皮細胞がTGF- $\beta$ の作用により，間葉系細胞の性質を獲得していることが 示された。この現象の分子機構について解析を進めたと ころ, TGF- $\beta$ 添加後 72 時間でも, 細胞内シグナル伝達因 子である Smad2のリン酸化が充進していることを見出し た。TGF- $\beta$ 様の液性因子の存在が示唆されたので, 関連
因子の発現を検討したところ，3種類ある TGF- $\beta$ のアイ ソフォームではなく, 類似シグナル因子である activin A を構成する inhibin $\beta \mathrm{A}$ の発現が立進しているとともに, この阻害因子である follistatinの発現が低下していた。以 上から、リンパ管内皮細胞において, TGF- $\beta$ によって誘 導されたEndMTは内因性のActivin A シグナルの増強に より EndMTが充進していくと考えられる（Fig. 2)。

\section{謝 辞}

本研究は, 東京大学大学院医学系研究科分子病理学分 野, 東京薬科大学腫湯医科学研究室, 東京医科歯科大学 分子細胞機能学分野/硬組織病態生化学分野で行われ た。とくに分子病理学分野の宮園浩平教授に心より深謝 申し上げます。また, 以上の研究室における共同研究者 の皆様のご尽力に感謝申し上げます。

\section{利益相反}

本研究に開示すべき利益相反はない。

\section{付 記}

本論文の要旨は第 60 回日本脈管学会総会学術委員会 シンポジゥム3（2019年, 東京）にて発表した。

\section{文献}

1) Wigle JT, Oliver G: Prox 1 function is required for the development of the murine lymphatic system. Cell 1999; 98: 769-778

2) Mishima K, Watabe T, Saito A, et al: Prox 1 induces lymphatic endothelial differentiation via integrin alpha 9 and other signaling cascades. Mol Biol Cell 2007; 18: 1421-1429 
3) Yoshimatsu Y, Yamazaki T, Mihira M, et al: Ets family members induce lymphangiogenesis through physical and functional interaction with Prox1. J Cell Sci 2011; 124: 2753 2762

4) Cao R, Bjorndahl MA, Religa $P$, et al: PDGF-BB induces intratumoral lymphangiogenesis and promotes lymphatic metastasis. Cancer Cell 2004; 6: 333-345

5) Miyazaki H, Yoshimatsu Y, Akatsu Y, et al: Expression of platelet-derived growth factor receptor $\beta$ is maintained by Prox 1 in lymphatic endothelial cells and is required for tumor lymphangiogenesis. Cancer Sci 2014; 105: 1116-1123

6) Oka M, Iwata C, Suzuki HI, et al: Inhibition of endogenous TGF-beta signaling enhances lymphangiogenesis. Blood 2008; 111: 4571-4579

7) Clavin NW, Avraham T, Fernandez J, et al: TGF-beta1 is a negative regulator of lymphatic regeneration during wound repair. Am J Physiol Heart Circ Physiol 2008; 295: H2113H2127

8) Ichise T, Yoshida N, Ichise H: FGF2-induced Ras-MAPK signalling maintains lymphatic endothelial cell identity by upregulating endothelial-cell-specific gene expression and suppressing TGF $\beta$ signalling through Smad2. J Cell Sci 2014; 127: $845-857$

9) Zolla V, Nizamutdinova IT, Scharf B, et al: Aging-related anatomical and biochemical changes in lymphatic collectors impair lymph transport, fluid homeostasis, and pathogen clearance. Aging Cell 2015; 14: 582-594

10) Yoshimatsu Y, Kimuro S, Pauty J, et al: TGF-beta and TNFalpha cooperatively induce mesenchymal transition of lymphatic endothelial cells via activation of Activin signals. PLoS One 2020; 15: e 0232356

\title{
Roles of Transcription Factors and Signaling Networks in the Regulation of Lymphatic Endothelial Cell Function
}

\author{
Yasuhiro Yoshimatsu ${ }^{1,2}$ and Tetsuro Watabe ${ }^{2}$
}

${ }^{1}$ Division of Pharmacology, Graduate School of Medical and Dental Sciences, Niigata University, Niigata, Japan

${ }^{2}$ Department of Biochemistry, Graduate School of Medical and Dental Sciences,

Tokyo Medical and Dental University (TMDU), Tokyo, Japan

Key words: Prox1, lymphatic endothelial cell, platelet-derived growth factor, Ets family transcription factor, transforming growth factor- $\beta$

The homeobox transcription factor Prox 1 is considered as a master regulator for the differentiation and function of lymphatic endothelial cells. To date, we identified Ets family transcription factors as a positive regulator of Prox1 function, and platelet-derived growth factor (PDGF) signal as a Prox1-regulated signal transduction pathway. In addition to them, we report, as a negative regulator of Prox 1 expression, transforming growth factor- $\beta$ (TGF- $\beta$ ), which is an inducer of endothelial mesenchymal transition (EndMT) in lymphatic endothelial cells, and its underlying molecular mechanism.

(J Jpn Coll Angiol 2020; 60: 193-196)

Online publication November 10, 2020 